\title{
Universities Upside Down: The Impact of the New Knowledge Economy
}

\author{
Margaret Thornton
}

En poursuivant le thème du $50^{e}$ anniversaire de l'Université York, soit «Knowledge Reconsidered: Feminism in the Academy at York» (Le savoir réexaminé : le féminisme dans les études universitaires à York), le présent article examine la révolution du savoir qui a lieu présentement à l'université. Au lieu d'adhérer au modèle de la science pour la science, comme l'a fait Newman, les universités partout jouent un rôle clé dans la production de nouveaux savoirs exigés par les États-nations. L'article traite aussi de l'effet de ces tendances globales sur la «marchandisation» du savoir ainsi que sur le transfert de la science. À la lumière de ces phénomènes surgit une question capitale : reste-t-il de la place, au sein de ce nouveau paradigme, pour la poursuite de recherches féministes, critiques et théoriques qui n'ont aucune valeur marchande?

Engaging with the fiftieth anniversary theme of "Knowledge Reconsidered: Feminism in the Academy at York," this presentation will consider the knowledge revolution that is presently occurring in the academy. Instead of pursuing knowledge for its own sake, à la Newman, universities everywhere are playing a key role in the production of new knowledge as required by nation states. The effect of global trends such as the commodification of knowledge and knowledge transfer will be addressed. The key question in light of these phenomena is what space is there within the new paradigm for the pursuit of feminist, critical, and theoretical knowledge that lacks market value?

\section{Introduction}

A large advertisement in an Australian newspaper caught my eye in late 2008. It was headed: "Entire University Campus for Lease: QUT Carseldine Campus, Queensland.' ${ }^{1}$ The fully equipped campus property of forty-five hectares was described as a desirable piece of real estate that was available for up to twenty-five years. However, what was not mentioned was of more

\footnotetext{
This article is based on a public lecture presented as the Barbara Betcherman Distinguished Visitor 2008, Osgoode Hall Law School, York University, Toronto, 15 October 2008. I express my gratitude for the generosity of the Betcherman family in funding the visitorship. I would like to thank Mary Jane Mossman for her exceptional hospitality and the Institute for Feminist Legal Studies at Osgoode Hall for hosting my visit. I also thank Trish Luker for research assistance.

1. Financial Review (15 September 2008) 36.
} 
interest to me. This was the fact that the campus, which had formerly housed the Queensland University of Technology's (QUT) Faculty of Arts, was closed down in July 2008 following a decision by university management. I had been a speaker at the faculty's "Last Post" colloquium in late 2007 when it was hoped that a change of federal government might win a reprieve, but it was not to be.

In order to replace the Faculty of Arts, the university had established a new Faculty of Creative Industries, which its website tells us offers "diverse and rewarding career opportunities"-presumably unlike the Faculty of Arts. Now, there is nothing wrong with creative industries, which include visual and performing arts, but where was the space to study the liberal arts-history, philosophy, classics, feminist, or Indigenous studies? There was none. ${ }^{2}$ The fate of QUT's Faculty of Arts is a graphic illustration of my thesis.

For centuries, the university has been viewed as the custodian of culture, the seat of higher learning and the paradigmatic site of free enquiry. These lofty aims have been turned upside down by a constellation of values emanating from the interstices of neo-liberalism, the new knowledge economy, and globalization. The result is that the university as a key knowledge producer is now primarily regarded as a source of wealth creation to be exploited. As the market enters the soul of the university, it has caused the commitment to the traditional values to contract.

This transformation first began to occur within the context of a notable swing to the right in global politics. Whereas social liberalism paid at least a modicum of attention to the idea of the public good, equality, and distributive justice, neo-liberalism shifted the focus from civil society to the market, with a correlative fixation on the interests of the individual and the accumulation of private wealth. To this extent, neo-liberalism has revived some of the tenets of classical liberalism, although it endorses a more positive conception of state power. ${ }^{3}$ It might be noted that Friedrich Hayek, who has been described as the father of neo-liberalism, emphasized the importance of knowledge as the key to economic growth in the 1930s and 1940s. ${ }^{4}$ However, it has taken the technological revolution for the significance of knowledge as a commodity to be realized, causing a shift away from land and physical resources. ${ }^{5}$ The new

2. Rather than a university, the Queensland University of Technology (QUT) has been described as now verging on a technical college. See Howard Guille, "The Last PostHumanities at QUT: Introduction" (2008) 5 Journal of the Public University, <http:// www.publicuni.org/journal/toc_05.html > .

3. Mark Olssen and Michael A Peters, "Neoliberalism, Higher Education and the Knowledge Economy: From the Free Market to Knowledge Capitalism" (2005) 20(3) Journal of Education Policy 313 at 315.

4. Friedrich Hayek, "Economics and Knowledge" (1937) 4 Econimica 33; Friedrich Hayek, "The Use of Knowledge in Society" (1945) 35(4) American Economic Review 519. Both articles are available at <http://www.hayekcenter.org/friedrichhayek/hayek.html > .

5. Francois Lyotard observed twenty years ago that knowledge had replaced land, raw materials, and cheap labour in the struggle for power among nation states. See Jean Francois 
knowledge economy nevertheless engenders risks that "haunt" 6 entrepreneurialism in ways that have not previously been known, as the contemporary global financial crisis reminds us. To abate the risk, it is believed that new knowledge must possess use value in the market.

In this article, I overview the trajectory of change from the emergence of the modern university and the contestation over the claim to the universality of knowledge by feminist scholars. As a touchstone in this respect, I will have recourse to a 1984 publication by the Canadian Research Institute for the Advancement of Women, edited by Ursula Franklin et al. and entitled Knowledge Reconsidered: A Feminist Overview. I then consider the paradigm shift in the academy arising from the emergence of the new knowledge economy and its ramifications for feminist knowledge. I suggest that the new knowledge economy has facilitated the remasculinization of the academy behind a façade of rationality, neutrality, and technocratic knowledge.

\section{The Idea of the University}

The inception of the modern university is marked by Von Humboldt's establishment of the University of Berlin in 1810. The modern university was concerned with the erudition, learning, and refinement of the emerging bourgeoisie rather than with mediaeval scholasticism or aristocratic noblesse oblige. Bourgeois revolutionary education was rational, universal, secular, and enlightened-values that came to represent the essence of a liberal university education. ${ }^{7}$ Cardinal John Henry Newman eloquently captures the idea of the university, the passing of which many rue, ${ }^{8}$ even though Newman's famous treatise is directed towards the education of Irish Catholic gentlemen. The kernel of the idea was that the university constituted a site of free inquiryhence its liberal descriptor. Thus, according to Newman, the university was not constrained by particular presuppositions, vocationalism, or practical skills. Even within a religious context, Newman considered the role of the university to be intellectual rather than moral. Most significantly, knowledge should be pursued for its own sake, not for instrumental reasons. Thus, the end of knowledge was knowledge itself. Newman identified the attributes of liberal

Lyotard, The Postmodern Condition: A Report on Knowledge (Manchester: Manchester University Press, 1984).

6. Jane Kenway et al. argue that the knowledge economy is perpetually haunted by risk. See Jane Kenway, Elizabeth Bullen, Johannah Fahey with Simon Robb, Haunting the Knowledge Economy (London: Routledge, 2006). For the by now classic study of risk, see Ulrich Beck, translated by M. Ritter, Risk Society: Towards a New Modernity (London: Sage, 1992).

7. Masao Miyoshi, "The University in the 'Global' Economy," in Kevin Robins and Frank Webster, eds., The Virtual University? Knowledge, Markets, and Management (Oxford: Oxford University Press, 2002) 49 at 52.

8. Stephen Rowland, "Collegiality and Intellectual Love" (2008) 29(3) British Journal of Sociology of Education 353. 
education as "freedom, equitableness, calmness, moderation, and wisdom." 9 Academic freedom as articulated by Newman was to become the leitmotif of the liberal incarnation of the university, which, at least in the abstract, allowed a thousand flowers to bloom.

While knowledge for its own sake has connotations of the ivory tower that serves no functional purpose, the crucial role of the modern university in preserving the culture of the nation state reveals that it actually serves several functions. First of all, the liberal ideal was a political tool for the creation of good liberal citizens, ${ }^{10}$ which is an idea that Newman himself supported. ${ }^{11}$ The study of the humanities and the natural sciences was believed to fashion character, although I reiterate that it was only the characters of upper class and bourgeois men that were of concern. Indeed, the elitism of the university was effectively deployed in the nineteenth century to exclude women and racialized Others as well as to suppress democratic moves by the working class. Overseas, this cultural elitism was invoked by European nations to promote notions of superiority over colonized peoples. Hence, the university supported imperialism and global capitalism as well as nationalism. Other instances of instrumentality are also discernible, such as the centrality of basic and applied science to the German university from the second half of the nineteenth century. Wilhelm von Humboldt, unlike Newman, believed in the linkage of teaching and research in the modern university. In addition, the nexus between the national defence system and the university in the United States in the midtwentieth century shows the importance of the applied research model, which was to become the linchpin of academic capitalism. ${ }^{12}$

Nostalgia for an idealized notion of the university in an age of overt functionality should not cause us to lose sight of the reality. The assumption that the university, as a site of liberal education, was formerly class free, unrestricted, self-motivated, and unbiased is a persistent myth. ${ }^{13}$ Nevertheless, first-wave feminists agitated to be let into this masculinist world, were inspired by the idealized vision of universality, neutrality, and objectivity. The emancipist focus was directed towards treating women as rational and fully human. $^{14}$

\footnotetext{
9. John Henry Newman, The Idea of a University, edited and introduced by I.T. Ker (Oxford: Clarendon [1852] 1976) at 96.

10. This idea was particularly strong in the United States. See Alan Ryan, Liberal Anxieties and Liberal Education (New York: Hill and Wang, 1998) at 95.

11. Newman, supra note 9 at 154 .

12. Gerard Delanty, "The University and Modernity: A History of the Present," in Kevin Robins and Frank Webster, The Virtual University? Knowledge, Markets, and Management (Oxford: Oxford University Press, 2002) 31 at 37.

13. Myoshi, supra note 7 at 53.

14. Pat Fitgerald, "A Woman Knows These Things: Women's Knowledge and Liberal Education," in Bob Brecher, Otakar Fleischmann, and Jo Halliday, eds., The University in a Liberal State (Avebury: Aldershot Hants, 1996) 37 at 39.
} 


\section{Knowledge Reconsidered}

By the late twentieth century, feminist acceptance of the claim to the universality of knowledge had lost some of its allure. Second-wave feminists were no longer content with merely being "let into" the academy as it was but, instead, sought to transform the nature of knowledge and the structures of power. The knowledge that had been assiduously safeguarded throughout the Western intellectual tradition and transmitted in the belief that it was objective, neutral, and true began to be dissected and exposed by feminist scholars as biased.

The feminist critique challenged the very presuppositions that had sustained the Western intellectual tradition. This is despite the fact that the interrogation of known knowledge underpinned the notion of free inquiry that is central to the liberal university. ${ }^{15}$ Unsurprisingly, what was perceived to be an epistemological assault on foundational knowledge was highly contentious. There was clearly a limit to critical thinking, which included challenging the dominant tradition of moral philosophy and culture that instructed women to be silent in the presence of men. ${ }^{16}$ This truism resulted in not just the devaluation of women's voices and ideas but also the difficulty of accepting women as authoritative knowers. The new feminist knowledge signalled a paradigm shift in the academic social order.

Across the disciplines, feminist scholars systematically revealed how the denigration of women's activities operated to augment male power and cohesion. ${ }^{17}$ Despite the resentment and antipathy, the new forms of knowledge gradually began to influence what is known and what is knowable, ${ }^{18}$ although masculinist skeptics remained unconvinced. The work of Canadian feminist theorists, such as the sociologist, Dorothy Smith, ${ }^{19}$ and the philosopher, Lorraine Code, ${ }^{20}$ were influential in developing new understandings of knowledge that drew on feminist subjectivities. The interdisciplinarity of

15. Paul Axelrod, Paul Anisef, and Zeng Lin, "Against All Odds? The Enduring Value of Liberal Education in Universities, Professions, and the Labour Market" (2001) 31(2) Canadian Journal of Higher Education 47 at 52.

16. Nannerl O Keohane, "Speaking from Silence: Women and the Science of Politics," in Elizabeth Langland and Walter Gove, eds., A Feminist Perspective in the Academy: The Difference It Makes (Chicago: University of Chicago Press, 1983) 86 at 92.

17. Cynthia Fuchs Epstein, "Women in Sociological Analysis: New Scholarship Versus Old Paradigms," in Langland and Gove, supra note 16, 149 at 151.

18. Elizabeth Langland and Walter Gove, "Editors' Notes," in Langland and Gove, supra note 16,1 at 2 .

19. Dorothy E. Smith, The Everyday World as Problematic: A Feminist Sociology (Milton Keynes: Open University Press, 1988); Dorothy E. Smith, Texts, Facts, and Femininity: Exploring the Relations of Ruling (London: Routledge, 1990).

20. Lorraine Code, What Can She Know: Feminist Theory and the Construction of Knowledge (Ithaca: Cornell University Press, 1991). 
women's studies was also a crucial aspect of the distinctiveness of feminist knowledge.

Nevertheless, any notion that the discourse of women's studies might have denoted a universal "woman" was soon scuttled. "She" was criticized for the insularity of her white, middle-class orientation. She lost her credibility because Indigenous women, non-English-speaking background women, lesbians, women with disabilities, and poor women felt marginalized. The implosion of the category woman coincided with the postmodern turn. French theorists, such as Michel Foucault, Jacques Derrida, Jean-Francois Lyotard, and Jacques Lacan, all similarly challenged the notions of universality and truth that had for so long been associated with the idea of the university. The ensuing culture wars highlighted the contestation over the authority of the incumbents and their right to map out the territory vis-à-vis feminist, postmodern, and cultural theory contenders.

The gatekeepers, however, claimed that the challengers lacked rigour and were "too political." They had an ideological standpoint, unlike the "benchmark men" of the academy who were presumably perched on an Archimedean pinpoint in their claim to universality and neutrality. The courses of the newcomers were denigrated, closed down, or made more anodyne and less threatening. In many institutions, women's studies disappeared in favour of more acceptable, de-gendered nomenclatures, such as diversity studies, for example.

Were these attacks crude manifestations of the backlash and ploys to safeguard the preserve of benchmark men or did they represent a new epistemic moment that signalled a shift away from the category woman? While "she" had served a useful political and legal purpose, was she now past her prime? Did the widespread disappointment in her also herald the shift away from one-dimensionality in favour of interrogating masculinity as well as indigeneity, sexuality, and post-coloniality? While some feminist scholars embraced postmodernism, acknowledging the one-dimensionality of the universal woman, others felt that the postmodern attack was a manifestation of a backlash that emerged just when women began speaking up for themselves. $^{21}$ It is difficult to disentangle the elements of backlash that seem to be a perennial counterpoint to women's struggle for acceptance within the academy. Despite the crisis of legitimation that postmodernism highlighted, a tsunami of far greater magnitude was about to envelope the university and change it irretrievably. Its potential for harm was also commensurably far greater and, as I will argue, more insidious.

21. Carol Nicholson, "Postmodern Feminisms," in Michael Peters, ed., Education and the Postmodern Condition (Westport, CT: Bergin and Garvey, 1995) 75 at 80. 


\section{Knowledge Capitalism}

What may be termed the third revolutionary phase in the history of the university, after modernization and feminization, is that of corporatization, which has emanated from the new knowledge economy. This phase has produced a string of new terms that only a short while ago would have been viewed as dissonant and disjunctive, such as "academic capitalism",22 and "the enterprise university." ${ }^{23}$ Regardless of the descriptor invoked, the reality is that the university is now the preeminent site of knowledge production deployed by contemporary nation states to generate wealth.

Alan Burton-Jones suggests that the change in favour of the new knowledge economy is as profound as the industrial revolution. ${ }^{24} \mathrm{He}$ explains that new knowledge is a form of capitalism with the same distinctive features as traditional capitalism:

Capitalism as we know it, and emerging Knowledge Capitalism, both thrive on capital accumulation, open market competition, free trade, the power of the individual, and the survival of the fittest. ${ }^{25}$

All capitalist economies now wish to exploit knowledge as an untapped source of wealth. The phenomenon has gathered momentum all over the world, not just in the West but also in China and Eastern Europe. Indeed, it is notable that nation states seeking to enhance their standing as new knowledge economies have the support of significant international bodies-the Organisation for Economic Co-operation and Development (OECD), ${ }^{26}$ the International Monetary Fund, ${ }^{27}$ and the World Bank ${ }^{28}$ - which are concerned

22. Sheila Slaughter and Larry L. Leslie, Academic Capitalism: Politics, Policies, and the Entrepreneurial University (Baltimore: Johns Hopkins, 1997).

23. Simon Marginson and Mark Considine, The Enterprise University: Power, Governance and Reinvention in Australia (Cambridge: Cambridge University Press, 2000).

24. Alan Burton-Jones, Knowledge Capitalism: Business, Work, and Learning in the New Economy (Oxford: Oxford University Press, 1999) at 3.

25. Ibid. at 20. Rather than viewing the late twentieth century incarnation of globalization as a new phase of capitalism, Meghnad Desai views it as the resumption of the nineteenthcentury variant with a socialist blip in-between. See Meghnad Desai, "Globalization, Neither Ideology Nor Utopia" (2001), < http://old.lse.ac.uk/collections/globalDimensions/ research/globalizationNeitherIdeologyNorUtopia/Default.htm $>$.

26. Brian Kahim and Dominique Foray, eds., Advancing Knowledge and the Knowledge Economy (Cambridge, MA: MIT Press, 2006). This collection arose from a project that was conducted with the OECD.

27. The International Monetary Fund hosted a major expo in 1998, entitled: "The Knowledge Economy," < http://www.imf.org/external/am/1998/expo.htm > .

28. World Bank, The Lessons of Experience (New York: World Bank, 1994); World Bank, Knowledge for Development: Capacity Building for the Knowledge Economy, <http:// web.worldbank.org/WBSITE/EXTERNAL/WBI/WBIPROGRAMS/KFDLP/0,,menuPK:

461238 pagePK:64156143 piPK:64154155 theSitePK:461198,00.html > . In other research, undertaken with the support of the World Bank, Bruce Johnstone et al. stress the need for 
to maximize productivity by fostering scientific and technological innovation. The global spread of the logic of the market renders the chances of resistance virtually impossible.

"New knowledge" is not knowledge in the sense of the accumulated fruit of wisdom referred to by Newman or knowledge that is associated with the transformative power of feminist knowledge envisaged by Ursula Franklin's Knowledge Reconsidered. ${ }^{29}$ New knowledge is a term of art that refers to useful knowledge (know-how as opposed to know-what) that may be utilized to impart skills to future new knowledge workers as well as to generate wealth. The notion of applied knowledge captures the slippage between "knowledge" and "information" that has occurred. The philosophical conditions for knowledge as traditionally understood-belief, truth, and justification-are not satisfied by information, which is defined as "data transmitted from a 'sender' to a 'receiver.", 30 Perhaps the most significant manifestation of the dystopian effect of the knowledge society is that knowledge is no longer viewed as wisdom but, rather, as data. ${ }^{31}$ Instead of the intellectual passion for ideas associated with scholastic and Enlightenment knowledge, there is now what has been described by Dominique Foray as a "wild passion for private property in the realm of knowledge creation." 32 This understanding has contributed to the manner in which bureaucratic and market discourse now invariably trumps academic discourse. ${ }^{33}$

The introduction of business principles into the university is not an altogether new phenomenon. The influential American theorist, Thorstein Veblen, who, like Newman, believed that the university was for the pursuit of knowledge for its own sake, identified the deleterious effects of business on universities a century ago. ${ }^{34}$ Nevertheless, the new managerialism that is

productivity. See D. Bruce Johnstone with Alka Arora and William Experton, The Financing and Management of Higher Education: A Status Report on Worldwide Reforms (New York: World Bank, 1998).

29. Ursula Martius Franklin, Michèle Jean, Sylvia van Kirk, Andrea Levowitz, Meg Luxton, Susan Sherwin, Dorothy E. Smith, Knowledge Reconsidered: A Feminist Overview (Ottawa: Canadian Research Institute for the Advancement of Women, 1984).

30. Michael Peters, "Universities, Globalisation and the Knowledge Economy" (2002) 35(2) Southern Review 16 at 27.

31. Helga Nowotny, Peter Scott, and Michael Gibbons, Re-Thinking Science: Knowledge and the Public in an Age of Uncertainty (Cambridge: Polity, 2001) at 12. The other elements of the "knowledge society" as dystopia that the authors identify are the promotion of inequality between the knowledge-rich and the knowledge-poor; the dissolution of traditional canons of art, ideas, and artefact; and the fact that it proliferates environmental, ethical, and intellectual risks.

32. Dominique Foray, "Optimizing the Use of Knowledge," in Kahim and Foray, supra note 26,9 at 13 .

33. Readings's discussion of the way the concept of excellence has become a vacuous marketing and bureaucratic tool illustrates the point. See Bill Readings, The University in Ruins (Cambridge, MA: Harvard University Press, 1996) at 21.

34. Thorstein Veblen, The Higher Learning in America: A Memorandum on the Conduct of Universities by Business Men (Stanford, CA: Academic Reprints [1918] 1954) at 135. 
orchestrated by a nation state, ${ }^{35}$ or a group of states, ${ }^{36}$ is infinitely more farreaching in its endeavours to deploy the new knowledge produced by universities for profit. Despite its potentially devastating effects for the future of the academy, the transformation of the university has been accepted with remarkable rapidity by faculty, students, and society at large, ${ }^{37}$ which has enabled the academic capitalist discourse to be normalized. The evisceration of academic authority in favour of top-down managerial power, underpinned by manifold technologies of audit, has ensured that academics have quickly learned to adapt to the new environment. In fact, this third paradigm shift attests to the effectiveness of managerial compliance mechanisms that have largely displaced academic debate. ${ }^{38}$

However, the public university is no longer certain of what it is for, as its orientation shifts from civil society to the market. Those parts of the university that are unable to demonstrate profitability face an uncertain future as indicated at the outset with the example of the QUT's Faculty of Arts. A similar pressure is confronting humanities and social sciences faculties elsewhere. ${ }^{39}$ They are beset with an anxiety to disprove any suggestion of "use-less-ness." A recent British Academy report, for example, sets out to prove that humanities and social sciences are functional in terms of wealth generation and contributions to public policy, health and well-being, and business. ${ }^{40}$ Even the United States, where higher education is diverse compared with other countries, has been profoundly affected by the intensity of change. ${ }^{41}$ Teaching and research have both been transformed by this academic capitalist environment but in very distinctive ways.

35. For example, Department for Education and Skills (UK), The Future of Higher Education (London: The Crown, 2003).

36. Europe and its member states have formulated the goal of making Europe one of the strongest knowledge societies in the world. The Bologna Declaration, $<$ http://ec.europa.eu/ education/policies/educ/bologna/bologna.pdf $>$ was a pledge by twenty-nine European countries in 1999 to reform and effect convergence of their structures of higher education. See also Communication from the Commission, The Role of the Universities in the Europe of Knowledge, Commission of the European Communities, Brussels, Doc. COM(2003) 58 final.

37. Myoshi, supra note 7 at 52.

38. Stephen Rowland, The Enquiring University: Compliance and Contestation in Higher Education (Maidenhead Berks: Society for Research into Higher Education and Open University Press, 2006) at 14.

39. Other Australian universities have responded by significantly pruning their humanities and social science offerings. The University of Western Australia, for example, is reported to have cut its undergraduate courses from seventy to six. See Luke Slattery, "Courses Trim for Global Outlook," The Australian (Higher Education) (24 September 2008) at 23.

40. British Academy, Punching our Weight: The Humanities and Social Sciences in Public Policy Making (London: British Academy, 2008), http://www.britac.ac.uk > ; LSE Public Policy Group, Maximizing the Social, Policy and Economic Impacts of Research in the Humanities and Social Sciences: Research Report (Supplementary Report) (London: London School of Economics and Political Sciences, 2008), < http://www.britac.ac.uk/reports/impact/index/ $\mathrm{cfm}>$.

41. Frank Newman, Lara Couturier, and Jamie Scurry, The Future of Higher Education: Rhetoric, Reality, and the Risks of the Market (San Francisco: Jossey-Bass, 2004). 


\section{Teaching: Students as Consumers}

Massification and privatization are the twin characteristics of the education revolution as the neo-liberal state abandons responsibility for funding public universities. The shift from élite to mass was symbolically effected in Australia in 1988 and in the United Kingdom in 1990 by converting colleges of advanced education and polytechnics respectively into universities overnight. The vastly increased number of students attending the new universities were not expected to be the beneficiaries of a liberal university education but, rather, were expected to be trained as productive workers who would augment the new knowledge economy. In fact, they would be more likely to have their horizons narrowed rather than broadened by their university experience in order to outfit them for the world of productive work. This phenomenon, which is by no means restricted to the new universities, is aptly described by Ann Bousfield as "vocationalising the curriculum." 42 It is distinguishable from embarking upon a specific vocational specialization, such as law. The effect of vocationalism has been to skew courses across the entire spectrum of the university towards applied fields and the acquisition of skills.

The trend towards privatization of so-called public universities emerges from treating education as a commodity. Again, Australia is a dramatic example since free higher education was an initiative of the Whitlam government in 1974. However, it is now an example of a user-pays system there as elsewhere. As fees are ratcheted up and students assume responsibility for more and more of the cost of their education, they have morphed into consumers, while academics have been relegated to the category of "providers." Universities must satisfy the demands of the student body, not only to maximize university income but also to attract the best students in order to increase their market share. ${ }^{43}$

Student/consumers are more likely to be interested in credentialism than the pursuit of a liberal education because they have one eye on ballooning education debt and one eye on an assured career path in an uncertain world that has reified the swing towards vocationalism. Commodification has encouraged a dilution or a sloughing off of the liberal curriculum altogether, a phenomenon that is notable in the case of law. ${ }^{44}$ Regardless of discipline,

42. Ann Bousfield, "The Voice of Liberal Learning: Is There Still Room for the 'Idea of a University' in 1996?" in Brecher, Fleischmann, and Halliday, supra note 14, 67 at 72.

43. A recent poll conducted in Australia found that 48 percent of the public viewed universities as being mainly concerned with operating as a business, whereas only 39 percent saw them as being mainly concerned with providing students with a good educational experience. See ANUpoll, Public Opinion towards Higher Education: Results from the ANU Poll, Report no. 2 (Canberra: Australian National University, September 2008) at 17.

44. For example, H.W. Arthurs, "The Political Economy of Canadian Legal Education" (1998) 25(1) Journal of Law and Society 14; Margaret Thornton, "The Demise of Diversity in Legal Education: Globalisation and the New Knowledge Economy" (2001) 8(1) International Journal of the Legal Profession 37; Margaret Thornton, "The Law School, 
the emphasis is now on marketable skills. Instrumentalism encourages a less reflexive, theoretical, and critical approach to the knowledge transmitted. ${ }^{45}$ The skills/applied focus is designed to appeal to prospective employers, thereby strengthening the conveyor belt between universities and business.

The shift to a user-pays model has also contributed to a resiling from the humanities in favour of business. Alan Ryan observes that in the United States, where the neo-liberal swing occurred earlier than elsewhere, Bachelor degrees in arts and sciences decreased from 47 percent to 26 percent between 1968 and 1986, whereas business degrees, which were formerly only one-third as numerous as degrees in arts and sciences, are now equally as numerous. ${ }^{46} \mathrm{~A}$ study of the Australian undergraduate enrolment data found that while there was an overall increase of 36 percent in the decade from 1994 to 2004, the proportion of students enrolled in management and commerce increased by 70 percent. ${ }^{47}$ Of course, business does not have to be taught in an applied way. It can include critical, prudential, and ethical dimensions, but, as already pointed out, commodification tends to promote a facilitative or "how-to" approach at the expense of critique.

Not only are business courses the most popular in the contemporary vocational university, but higher education itself has become a business or an industry, signifying its changed conceptualization in terms of the market. In Australia, higher education surpassed tourism in 2007 as the third biggest export earner after coal and iron. ${ }^{48}$ Once again, it is business that embodies the international language of communication, which is most sought after by international students. As the new knowledge economy has become essential to nation states, they have a vested interest in a regime that privileges the transmission of applied knowledge over critical and theoretical knowledge.

\section{Research: Knowledge Transfer}

While the neo-liberal state might have largely resiled from its financial responsibility for public universities, it continues to micromanage them, thereby acting as the driver of the new knowledge economy. It is notable that it

the Market and the New Knowledge Economy" (2007) 17 (1 and 2) Legal Education Review 1.

45. Freire's banking metaphor aptly captures the approach. See Paolo Freire, Pedagogy of the Oppressed, translated by M.B. Ramos (New York: Continuum, 1996) at 53-7.

46. Ryan, supra note 10 at 148.

47. Kerri-Lee Krause, Robyn Hartley, Richard James, and Craig McInnes, The First Year Experience in Australian Universities: Findings from a Decade of National Studies, Centre for the Study of Higher Education (Canberra: University of Melbourne for Department of Education, Science and Training, 2005) at 80.

48. The industry is now worth more than AUS $\$ 15$ billion. 
has not only orchestrated research to maximize wealth production, but it has also permitted the benefits of that wealth to be privatized. In the process, the state has ceded significant control over knowledge production to the private sector. It is somewhat paradoxical that the resources of public universities are now being used for the private good of corporations, which signifies just how dramatic is the shift away from the values of social liberalism. Technoscience is favoured because it is the most lucrative. Claire Polster observes that the enhanced role of industry in research has had disastrous results for the social sciences and the humanities in Canada because of the way it has skewed research towards industrially related knowledge. ${ }^{49}$ To this extent, the production of new knowledge is a variation on a theme, following the commodification of teaching.

Technology transfer is the key to academic capitalism so far as research is concerned. This means that the outcomes of research cannot be permitted to lie fallow (knowledge for its own sake) within the academy but must be made to serve a useful purpose, such as being deployed to resolve practical problems or generate wealth. The transfer of the knowledge to corporations with the capacity to exploit its potential is therefore seen as highly desirable.

In the United States and Britain during the terms of Ronald Reagan and Margaret Thatcher, the use of public resources for the benefit of private enterprise rapidly gained in popularity in accordance with the neo-liberal agenda ${ }^{50}$ The 1980 Bayh-Dole Act in the United States allowed universities themselves to commercialize inventions developed through federally funded research programs. ${ }^{51}$ Universities are therefore intent on forming partnerships with industry to secure research funding in anticipation of future collaboration and commercialization.

Entrepreneurialism, commercialization, and technology transfer have become primary aims of contemporary universities everywhere. The website of the venerable University of Edinburgh is exemplary. ${ }^{52}$ It specifies three strategic goals: excellence in learning and teaching, excellence in research, and excellence in commercialization and knowledge exchange. It can be seen that knowledge transfer and the generation of profits have been elevated to the same status as the traditional university mission of teaching and research. Millions of dollars are being generated from joint enterprises at the University of Edinburgh, as elsewhere.

49. Claire Polster, "Dismantling the Liberal University: The State's New Approach to Academic Research," in Brecher, Fleischmann, and Halliday, supra note 14, 106 at 106. See also Axelrod, Anisef, and Lin, supra note 15.

50. Myoshi, supra note 7 at 60.

51. Bayh-Dole Act, 35 U.S.C. 200-12.

52. University of Edinburgh website, <http://www.planning.ed.ac.uk/Strategic_Planning/ SP2008-12/SP0812.htm > . 
By constantly emphasizing the economic role of the university, we are moving away from the social justification for its existence, which is the essence of the public good:

Technology transfer via the patent system is by definition not a public good. The public good aspect remains the conventional one: the outputs of teaching and basic research. ${ }^{53}$

There are also other negative social effects of the economic rationality of neoliberalism, in that making a profit is of pre-eminent importance and what happens to people is incidental. This is the essence of the shift from social to neo-liberalism - from the collective good to the right of the few to maximize wealth at the expense of the majority. Ursula Franklin made a similar observation about technical innovation in Knowledge Reconsidered in $1984 .^{54}$ Thus, it is in the interstices of the technocratic and the profitable that the explanation for the resiling from feminist scholarship can be found.

\section{Academic Capitalism and the Remasculinization of the Academy}

I have already noted that the new knowledge society is more concerned with the transmission of data than the pursuit of wisdom ("know-how" rather than "know-what"). Understanding and critiquing new knowledge is not a dimension of the present agenda, and the undervaluation of the humanities and the sloughing off of the social have profoundly contracted the traditional spaces for critique. ${ }^{55}$ Not only is critique deemed to lack use value in the market, but it is also likely to be discomfiting to corporations that would prefer not to have their business practices exposed. Thus, the critical pursuit of knowledge for its own sake is out of favour, not only because it is perceived to be unprofitable in terms of knowledge transfer but also because neo-liberals are suspicious of its very raison d'être. Law and business are notable examples of the shift away from the prudential towards the applied in their curricular orientation - a factor that is not without significance at a time of large-scale corporate collapse and executive greed.

I would also suggest that the new knowledge economy is deeply gendered, despite its best endeavours to present a neutral facade to the world. In one

53. Robin Cowan, "Universities and the Knowledge Economy," in Kahim and Foray, supra note 26,135 at 140 .

54. Ursula Martius Franklin, "Will Women Change Technology or Will Technology Change Women?" in Ursula Franklin et al., supra note 28, 77 at 83.

55. Margaret Thornton, "The Dissolution of the Social in the Legal Academy" (2006) 25 Australian Feminist Law Journal 3; Margaret Thornton, "The Retreat from the Critical: Social Science Research in the Corporatised University" (2008) 50(1) Australian Universities Review 5. 
sense, capitalism has little incentive either to eradicate or to encourage racism or sexism, ${ }^{56}$ but if the market can deploy sex and sexuality for profits it will do so. ${ }^{57}$ However, there is a concealed manifestation of anti-feminism lurking beneath the surface of the new knowledge economy and embedded within its technologies of power. ${ }^{58}$ In this regard, it is not so much the gender of the social actors that drive the present climate as the new ideologies. ${ }^{59}$

In their description of the academic subject, Jane Kenway, Elizabeth Bullen, Johannah Fahey, and Simon Robb capture the subtle incarnation of gender that emerges as "technopreneurial," which refers to the way the favoured techno-scientific knowledge is combined with business acumen. ${ }^{60}$ The technopreneur works alone, taking risks and promoting the self, unconcerned about collegiality and the collective good, since the intensification of the economic function of knowledge has come at the expense of the social function. ${ }^{61}$ Picking up on the masculinized character of the technopreneur, Henry Giroux graphically describes the American university post-9/11 as a "militarized knowledge factory." 62 He suggests that the hatred of democracy and dissent in an authoritarian neo-liberal environment has given rise to a politics of "militarized masculinity," associated particularly with the war in Iraq and the domestic war on terror, which mark the return of the "warrior male,"

whose paranoia is endlessly stoked by the existence of a feminized culture of critical thinking, a gay subculture and a liberal ideology that exhibits a disrespect for top-down order and unquestioned authority and discipline. ${ }^{63}$

Universities as "militarized knowledge factories" are not involved in producing conventional soldiers so much as producing graduates with a uniform habit of mind that happens to be deeply gendered. More is at stake

56. Myoshi, supra note 7 at 74 .

57. The phenomenon of girl power, which focuses on sexy fashions for young women is one example of this. See, for example, Chilla Bulbeck, "Explaining the Generation Debate: Envy, History or Feminism's Victories?" (2006) 15 Lilith 35; Angela McRobbie, "Top Girls?" (2007) 21(4) Cultural Studies 718.

58. Ursula Franklin noted in 1984 how technology was grafted onto traditional masculinist notions of power that replaced the old social order. See Franklin, supra note 54 at 83.

59. Magda Lewis, "More Than Meets the Eye: The Under Side of the Corporate Culture of Higher Education and Possibilities for a New Feminist Critique" (2005) 2(1) Journal of Curriculum Theorizing 7 at 10.

60. Kenway et al., supra note 6 at 42 .

61. Ibid.

62. Henry A. Giroux, "The Militarization of US Higher Education after 9/11" (2008) 25 Theory Culture Society 56. Compare with John Armitage, "Beyond Hypermodern Militarized Knowledge Factories" (2005) 27(3) Review of Education, Pedagogy, and Cultural Studies 219.

63. Giroux, supra note 62 at 61. 
here than simply affirming the stereotypical conjunction between militarism and masculinity. The denigration of the feminine emerged with the populist neo-conservative attack on tertiary educated "élites" who were concerned about social justice, rights for Indigenous people, same sex couples, and welfare rights. ${ }^{64}$ It is perhaps unsurprising that this populist form of anti-feminism first emerged in the United States and then later surfaced in new guises in other Anglophone countries, such as Canada and Australia. ${ }^{65}$

In an attempt to reclaim "authentic manliness" through technocratic new knowledge, the act of critique, which is the essence of liberal academic life within these new "knowledge factories," is currently depicted as feminized and dispensable. It is assumed that technocratic and applied knowledge, delivered as information, does not need to be interpreted - it speaks for itself. The most effective way of dispensing with critique is to contract the space that enables it, which is disastrous for projects such as feminism, which is necessarily a critical project. The evisceration of this space has enabled anti-feminism to be revived within the new knowledge scripts of the academy even though, as Magda Lewis points out, terms such as patriarchy and sexism have become anachronistic because of the ideological shifts that have occurred. ${ }^{66}$ However, gender does not go away. As Dorothy Smith observed twenty-five years ago, it remains integral to social relations:

The apparently neutral and impersonal rationality of the ruling apparatus is, in fact, organized by gender. The male subtext concealed beneath its apparently impersonal forms is integral, not accidental. ${ }^{67}$

It is therefore unsurprising that the gendered subtext has adapted to the new circumstances and new ideologies. New knowledge is the apparatus that enables a new form of gender to be produced-new knowledge is not degendered as its technocratic veneer would have us believe. Thus, while the gendered identity of academic subjects no longer ostensibly counts as much as their productivity, the gendered subtext of the new knowledge economy is subtly reified. Competition policy and the logic of the market necessarily produce inequality, not equality, and it is notable that there has been a resiling

64. See Damien Cahill, "New-Class Discourse and the Construction of Left-Wing Elites," and other essays in Marian Sawer and Barry Hindess, eds., Us and Them: Anti-Elitism in Australia, API Network (Perth: Curtin University of Technology, 2004).

65. Marian Sawer, "Populism and Public Choice in Australia and Canada: Turning EqualitySeekers into 'Special Interests," in Sawer and Hindess, supra note 64.

66. Lewis, supra note 59 at 11.

67. Dorothy Smith, "The Renaissance of Women," in Ursula Franklin et al., supra note 29, 3 at 7. 
from the language of equality and equality of opportunity in the academy as well as in public policy more generally. ${ }^{68}$ The legitimation of inequality tilts the scales permanently in favour of the status quo. In addition, neo-liberalism has generally seen an erosion of progressive public interest policies in favour of individualism, which has impacted disproportionately on women. ${ }^{69}$ Promotion of the self through neo-liberal rationality has effectively displaced a collective commitment to gender politics in the academy, which has spilled over into the constitution of knowledge.

\section{Conclusion}

The transformation of the university through the targeting of funds for commercial research, privatization, and corporatization has not only exerted a profound effect on what is taught, what is researched, and what is valued, it has been suggested that it is causing the disintegration of the university. ${ }^{70}$ Xiaoying Wang suggests that the university will soon "cease to be an institution informed by intellectual autonomy; instead, it will become an appendage of corporations ... tailored to the needs of industry and commerce." ${ }^{71}$ In the United States, there is a large number of corporate universities, including McDonalds and Motorola. These giant functionaries are paradigmatic transmitters of new knowledge that are dedicated to serving corporate interests, with no interest in critique or the questioning of orthodoxy. Public universities also appear to be headed in a similar direction.

How did academics come to accept the new regime with so little resistance? It is not just a question of being directed from above but that they themselves have become "active subjects" in the new regime. ${ }^{72}$ This entails academics

68. Janine Brodie, "We are All Equal Now: Contemporary Gender Politics in Canada" (2008) 9 Feminist Theory 145; Margaret Thornton, "EEO in a Neo-Liberal Climate" (2001) 6(1) Journal of Interdisciplinary Gender Studies 77; Margaret Thornton, "The Evisceration of EEO in Higher Education" (2008) 50(2) Australian Universities Review 59. In September 2008, the Australian Human Rights and Equal Opportunity Commission dropped the phrase "equal opportunity" from its name.

69. Anne Summers, The End of Equality: Work, Babies and Women's Choices in the TwentyFirst Century (Sydney: Random House, 2003); Marian Sawer, "From Women's Interests to Special Interests: Reframing Equality Claims," in L. Chappel and L. Hill, eds., The Politics of Women's Interests (London: Routledge, 2006).

70. Slaughter and Leslie, supra note 22 at 243. Compare with Xiaoying Wang, "Farewell to the Humanities" 17(4) (2005) Rethinking Marxism 525 at 537.

71. Wang, supra note 70 at 533 .

72. Maurizio Lazzarato, "Immaterial Labor," in Paolo Virno and Michael Hardt, eds., Radical Thought in Italy: A Potential Politics (Minneapolis: University of Minnesota Press, 1996) 130 at 134. 
managing themselves so that they are ever more productive in ways that best suit the new knowledge economy:

The fact that immaterial labor produces subjectivity and economic value at the same time demonstrates how capitalist production has invaded our lives and has broken down all the oppositions among economy, power, and knowledge. ${ }^{73}$

The web of governmentality in which academic subjects are now enmeshed ensures compliance for they inhabit an audit culture that requires constant demonstration of their productivity. Resistance may invite disapprobation, disciplinary action, and even retrenchment, all of which are salutary disincentives for would-be dissidents. As a dimension of governmentality, conformity, rather than difference or distinctiveness, typifies the corporatized university, which has profound implications for academic freedom. It is predicted that the struggle over the meaning and value of knowledge will continue to be a feature of the "education wars." 74 The corporatization of the university means that the struggle over knowledge is more likely to be between management and academics than to be solely an intellectual debate, although politics and ideology are always going to be imbricated in it since knowledge is the primary site of power.

The Canadian scholar, Claire Polster, asserts that the only response to university/industry research links is to "get rid of them."75 However, it is unimaginable that things might revert to the way they were because the higher education sector has come to rely on the wealth generated through academic capitalism. The ploy by neo-liberal governments to reduce the operating grants of public universities was a brilliant move, for it guaranteed compliance with the commercialization imperative. Universities had no option but to enter the market. This enabled them to justify fee hikes and questionable liaisons with industry on the ground of necessity, assuaging public criticism with a handful of scholarships and tokenistic gestures in support of the humanities and social sciences. Students - and their parents - also then became enmeshed in what one may liken to a system of infeudation. Hence, I agree with Michael Peters that, far from being able to end the liaison between public education and business, it is likely to become even stronger:

In the age of knowledge capitalism, we can expect governments in the West to further ease themselves out of the public provision of

\section{Ibid. at 142 .}

74. Olssen and Peters, supra note 3 at 340 .

75. Claire Polster, "Rethinking and Remaking Academic Freedom," in Denise DohertyDelorme and Erika Shaker, Missing Pieces V: An Alternative Guide to Canadian PostSecondary Education (Ottawa: Canadian Centre for Policy Alternatives, 2004) at 96. 
education as they begin in earnest to privatise the means of knowledge production and experiment with new businesses and public education at all levels. ${ }^{76}$

All the signs, including the facilitative roles of multinational corporations and supranational bodies, such as the OECD, point in this direction. New knowledge and capital have become so thoroughly entwined within the "knowledge economy" that they cannot be disentangled. After an inordinately short time, feminist knowledge, in all of its guises, appears to have become shadowy and elusive within the academy once more.

In light of the way women's voices have been systematically erased within the Western intellectual tradition, Dorothy Smith anticipated twenty-five years ago the likelihood of a further period of erasure if an institutional base was not secured for feminist scholarship:

Without access to this institutional process, we will see again what we have seen in the past: the disappearance of a knowledge of women from the public social discourse. ${ }^{77}$

Women did secure an institutional base in the academy as both students and academics, but this was not enough to safeguard the place of feminism in the academy, for it is primarily as neo-liberal subjects that academics are now valued. In this capacity, feminist scholars are expected to serve the new knowledge economy rather than critique it. The homologous relationship between critique and feminism means that the contraction of the critical space necessarily also leads to the contraction of feminism within the academy.

Feminist studies were abolished at QUT when the Faculty of Arts was closed down because the humanistic and the social were no longer viewed as valuable. Ironically, the replacement Faculty of Creative Industries has been reported as experiencing similar experiences to that of the former faculty. Its teaching program has acquired a deficit, there is a high attrition rate, and it has difficulty in meeting its marketing promise of preparing graduates at the "forefront of entrepreneurial, cultural and creative developments." ${ }^{78}$ Trying to transmute the humanities into an industry in the interest of profit making can only do further damage to what is left of the idea of the university. The QUT experience might be viewed as salutary for other Western new knowledge economies.

76. Peters, supra note 30 at 165.

77. Smith, supra note 67 at 11.

78. QUT, Creative Industries Faculty Review, Final Report, 2-5 April 2007 at 14, cited in Guille, supra note 2. 
It is imperative that feminist and progressive scholars continue to exercise the vital academic role of critic and conscience of the new knowledge economy rather than being mere players and pawns in its promotion. Acquiescence in the corporatized role of neo-liberal subjects is not only hastening the conversion of universities into giant technological and profit-making institutions in the interests of the state, but it is also ensuring their masculinization. 